\title{
Data report: permeability of sediments from Sites C0011 and C0012, NanTroSEIZE Stage 2: subduction inputs ${ }^{1}$
}

\author{
Brandon Dugan² and Xin Zhao ${ }^{2}$
}

\section{Chapter contents}

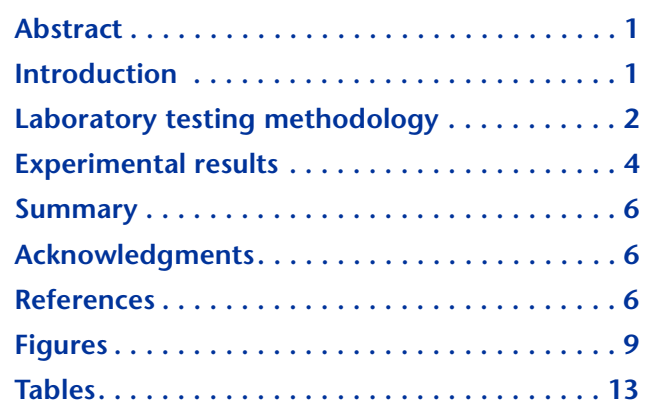

'Dugan, B., and Zhao, X., 2013. Data report: permeability of sediments from Sites C0011 and C0012, NanTroSEIZE Stage 2: subduction inputs. In Saito, S., Underwood, M.B., Kubo, Y., and the Expedition 322 Scientists, Proc. IODP, 322: Tokyo (Integrated Ocean Drilling Program Management International, Inc.).

doi:10.2204/iodp.proc.322.208.2013

${ }^{2}$ Department of Earth Science, Rice University, Houston TX 77005, USA. Correspondence author: dugan@rice.edu

\section{Abstract}

Constant rate of strain (CRS) consolidation experiments and flowthrough permeability experiments are used to characterize the flow behavior of hemipelagic mudstones at Integrated Ocean Drilling Program Sites C0011 and C0012. Flow-through permeability experiments on samples from Site C0011 (366.76-687.15 meters below seafloor [mbsf]) provide estimates of vertical permeability $\left(k_{\mathrm{v}}\right)$ that range from $7.03 \times 10^{-17}$ to $1.38 \times 10^{-18} \mathrm{~m}^{2}$. Flowthrough experiments on samples from Site C0012 (273.51-473.11 mbsf) provide estimates of in situ $k_{\mathrm{v}}$ from $6.09 \times 10^{-19}$ to $2.86 \times 10^{-19}$ $\mathrm{m}^{2}$ and in situ horizontal permeability $\left(k_{\mathrm{h}}\right)$ of $6.54 \times 10^{-19} \mathrm{~m}^{2}$. At Site C0012 (115.44-255.31 mbsf), CRS-based estimates of in situ $k_{\mathrm{v}}$ range from $1.12 \times 10^{-17}$ to $2.54 \times 10^{-18} \mathrm{~m}^{2}$ and in situ $k_{\mathrm{h}}$ ranges from $1.66 \times 10^{-17}$ to $6.55 \times 10^{-18} \mathrm{~m}^{2}$. For the four depths at Site C0012 where vertical and horizontal permeability calculations were made, the permeability ratio $\left(k_{\mathrm{v}} / k_{\mathrm{h}}\right)$ ranges from 0.38 to 0.99 . Where calculated, $k_{\mathrm{v}} / k_{\mathrm{h}}$ does not show any depth trends.

Neglecting one anomalous data point, all data show permeability decreases with increasing depth and decreasing porosity. Flowthrough data document greater permeability at Site C0011 compared to Site C0012 at equivalent depths below $350 \mathrm{mbsf}$. In lithologic Units III and IV, permeability estimated by flow-through experiments at Site C0011 is greater than at Site C0012. Drilling and coring disturbance exists in all samples and adjacent shipboard samples, suggesting that all permeability estimates have been impacted by sample disturbance, should be viewed with caution, and should be considered an upper limit on in situ permeability.

\section{Introduction}

During Integrated Ocean Drilling Program (IODP) Expedition 322, research was conducted to understand the sedimentology, physical properties, and sediment and fluid chemistry of input sediments to the Nankai accretionary complex and subduction zone (see the "Expedition 322 summary" chapter [Underwood et al., 2010]). The research objectives of Expedition 322 are part of the overall research objectives of the Nankai Trough Seismogenic Zone Experiment (NanTroSEIZE) to constrain, monitor, and understand faulting and seismogenesis along megathrusts (Tobin and Kinoshita, 2006). 
To contribute to the NanTroSEIZE research objectives, we calculated the permeability $(k)$ of input sediments to the subduction zone. We subsampled whole-round samples collected from IODP Sites C0011 and C0012 (Fig. F1) during Expedition 322 for constant rate of strain (CRS) consolidation experiments and flow-through permeability experiments to estimate permeability. Original whole-round samples and experimental subsamples were hemipelagic mudstone, as determined by shipboard and shorebased inspection. We focused on hemipelagic mudstones to constrain the bulk behavior of one lithologic type. We completed seven vertical permeability calculations for specimens from Site C0011, eight vertical permeability calculations for specimens from Site C0012, and four horizontal permeability calculations for specimens from Site C0012 (Table T1). These data help define the permeability behavior at Site C0011 from 366.76 to 687.15 meters below seafloor (mbsf) and at Site C0012 from 115.44 to 473.11 mbsf. These results complement other permeability analyses within NanTroSEIZE (Boutt et al., 2012; Dugan and Daigle, 2011; Ekinci et al., 2011; Guo et al., 2011; Hüpers and Kopf, 2012; Ikari et al., 2009; Reuschle, 2011; Rowe et al., 2011; Saffer et al., 2011; Yue et al., 2012). Flow properties studies can be coupled with grain-size and sedimentological studies (e.g., Kopf et al., 2011; Guo and Underwood, 2012) to help define the relation between lithology and permeability (e.g., Schneider et al., 2011). The permeability behavior is also integral to numerical modeling studies aimed at understanding the coupling of deformation and fluid flow within the NanTroSEIZE accretionary complex (e.g., Rowe et al., 2012). Numerical models using laboratory results as inputs and constraints can be used to understand the fluid budget of the Nankai accretionary complex and its input sediments. This also helps constrain solute and energy transport in the Nankai Trough region. The integration of numerous geotechnical, sedimentological, and hydrological studies through the NanTroSEIZE project will contribute to our knowledge of the coupling between flow, deformation, and strength in accretionary complexes.

\section{Laboratory testing methodology}

Whole-round core samples from Sites C0011 and C0012 (Fig. F1; Table T1) were capped and sealed after collection and stored at $4^{\circ} \mathrm{C}$ to help maintain the natural water content. All whole-round samples were selected to isolate samples that were hemipelagic mudstone. Samples were taken out of the sealed core liner to conduct CRS consolidation experiments and flow-through permeability experiments following
American Society for Testing and Materials (ASTM) International standards (ASTM International 2004, 2006). All experiments are performed at room temperature $\left(20^{\circ} \mathrm{C}\right)$.

\section{CRS consolidation experiments}

The consolidation system at Rice University (USA) can achieve a maximum consolidation stress of $\sim 4200 \mathrm{kPa}$, which equates to a burial depth of $\sim 500$ mbsf for normal hydrostatic conditions. We limit CRS experiments to specimens from depths shallower than 300 mbsf to allow for elastoplastic consolidation even if specimens are overconsolidated. CRS experiments were completed in a rigid confining ring to maintain the uniaxial strain of the specimen. Each specimen was trimmed using a trimming jig, a wire saw, and a sharp-edged spatula to minimize disturbance during preparation and to provide a specimen diameter that was the exact diameter of the rigid confining ring. Samples were trimmed in a vertical orientation to allow assessment of vertical permeability $\left(k_{\mathrm{v}}\right)$ or in a horizontal orientation to allow assessment of horizontal permeability $\left(k_{\mathrm{h}}\right)$. Once the specimen was in the confining ring, a wire saw, a sharp-edged spatula, and a recess tool were used to make the specimen into a right cylinder of a fixed height. The use of the trimming jig, confining ring, and recess tool facilitate making specimens of identical diameter and height. Each specimen had an initial height $\left(H_{\mathrm{o}}\right)$ of $2.41 \mathrm{~cm}$ and an initial diameter of $5.09 \mathrm{~cm}$. A constant, controlled cell pressure $\left(P_{\mathrm{c}}\right)$ $(386 \mathrm{kPa})$ was applied to each specimen to ensure saturation with an idealized seawater solution. An initial saturation period of at least $8 \mathrm{~h}$ was used to make sure the specimen was at $100 \%$ saturation. Then the specimen was uniaxially deformed at a constant rate of strain. The strain rate $(\dot{\varepsilon})$ was adjusted for each specimen to ensure a pore pressure ratio $<0.10$ (ASTM International, 2006). The pore pressure ratio depends on the strain rate and the permeability of the specimen. Total axial stress $\left(\sigma_{a}\right)$, instantaneous sample height $(H)$, and basal pore pressure $\left(P_{\mathrm{p}}\right)$ were recorded throughout the experiment. Each experiment was completed at a maximum consolidation stress exceeding the hydrostatic effective vertical stress $\left(\sigma_{\mathrm{vh}}{ }^{\prime}\right)$ for the specimen; $\sigma_{\mathrm{vh}}{ }^{\prime}$ is total vertical stress less hydrostatic fluid pressure and is determined by integrating the bulk density data. The maximum consolidation stress $\left(\sigma_{v}{ }^{\prime}\right.$ max $)$ for each experiment was chosen to be at least three times $\sigma_{\mathrm{vh}}{ }^{\prime}$ for the specimen in that experiment (Table T2). This allowed reaching elastoplastic or virgin consolidation even for samples with mild overconsolidation. Routine inspection of consolidation curves con- 
firmed that each specimen reached elastoplastic deformation. Total vertical stress was determined from bulk density $\left(\rho_{\mathrm{b}}\right)$ data (see the "Site C0011" and "Site C0012" chapters [Expedition 322 Scientists, 2010a, 2010b]). Hydrostatic fluid pressure was calculated assuming a constant seawater density $\left(\rho_{\mathrm{w}}=\right.$ $\left.1024 \mathrm{~kg} / \mathrm{m}^{3}\right)$.

CRS consolidation experiments provide data to constrain hydraulic conductivity $(K)$ for laboratory conditions (ASTM International, 2006), which can be converted to permeability $\left(k=K \mu / \rho_{\mathrm{w}} \mathrm{g}\right)$ based on the water density $\left(\rho_{\mathrm{w}}=1024 \mathrm{~kg} / \mathrm{m}^{3}\right)$ and viscosity $(\mu=$ $0.001 \mathrm{~Pa} \cdot \mathrm{s})$ at laboratory conditions:

$$
\mathrm{k}=\dot{\varepsilon} H H_{\mathrm{o}} \mu / 2 \Delta u,
$$

where

$$
\begin{aligned}
& \dot{\varepsilon}=\text { strain rate } \\
& H_{\mathrm{o}}=\text { initial specimen height } \\
& H=\text { instantaneous specimen height, and } \\
& \Delta u=\text { base excess pressure }
\end{aligned}
$$

Base excess pore pressure is defined as the difference between basal pore pressure and cell pressure $\left(P_{\mathrm{c}}\right)$ :

$$
\Delta u=P_{\mathrm{p}}-P_{\mathrm{c}} .
$$

A smoothed base excess pore pressure, based on a three-point moving average, is used. A six-point moving average is used to smooth the strain rate.

We use permeability-porosity $(k-\phi)$ data during normal consolidation to define a log-linear relation between $k$ and $\phi$ for each specimen (e.g., Neuzil, 1994; Schneider et al., 2011). Each specimen-specific model is used to estimate permeability at the in situ porosity. We assume that the porosity at the laboratory-determined preconsolidation stress of each specimen represents the in situ porosity. Preconsolidation stresses were determined using the workstress method (Becker et al., 1987). This method defines the preconsolidation stress as the intersection of the linear extensions of the elastic and elastoplastic deformation curves in work-stress space, which provides a well-defined estimate the preconsolidation stress even if the transition from elastic to elastoplastic deformation is not well defined. Laboratory-derived in situ porosity for each specimen compares well to shipboard porosity data (Fig. F2). Initial specimen porosity was determined in our laboratory from mass and density measurements following the approach presented by Blum (1997). As the sediments are clay rich containing smectite and illite, these shipboard and shore-based porosity data may overestimate the in situ porosity. The exact magnitude of porosity change is controlled by the sample porosity and smectite content. Previous studies of Nankai sediment show that corrections for smectite content can yield porosity up to $16 \%$ lower than shipboard-determined porosity (e.g., shipboard porosity of 33\% and smectite content-corrected porosity of 17\%) (Gamage et al., 2011). Porosity corrections for the samples in this study could be made based on the bulk sediment smectite content, which is 33-55 wt\% for samples from Site C0011 and 31-55 $\mathrm{wt} \%$ for samples from Site C0012 (Underwood and Guo, 2013). In addition, shipboard mass and density porosity data have significant variability that has been interpreted as a result of significant coring disturbance (see the "Site C0011" and "Site C0012" chapters [Expedition 322 Scientists, 2010a, 2010b]). This suggests that mass and density and laboratory porosity are a high estimate of the in situ porosity. Therefore, when we refer to in situ permeability, it should be noted that it is the estimated permeability at the high-end estimate of in situ porosity for all specimens. Porosity during consolidation was determined using the strain data. This approach allows us to present the horizontal or vertical permeability for each CRS specimen, depending on its orientation, at the in situ porosity and at its sample depth (Table T2; Figs. F3, F4). For depths where a horizontal and a vertical specimen were tested, we also provide the ratio of these permeabilities $\left(k_{\mathrm{v}} / k_{\mathrm{h}}\right)$ (Table T2).

\section{Flow-through permeability experiments}

Permeability experiments are completed on cylindrical specimens in a flexible-wall membrane. Each specimen was trimmed using a trimming jig, a wire saw, and a sharp-edged spatula to minimize disturbance during preparation and to provide a uniform specimen diameter. Samples were trimmed in a vertical orientation to allow assessment of $k_{\mathrm{v}}$ or in a horizontal orientation to allow assessment of $k_{\mathrm{h}}$. Specimen length and diameter varied depending on the ability to get an intact specimen (influenced by sample disturbance from drilling and coring), but in general, diameter was near $5.08 \mathrm{~cm}$ and length was at least $3.86 \mathrm{~cm}$. Each specimen was placed in an impermeable, flexible-wall membrane, and porous stones were placed on the ends. Each specimen was then loaded in the permeability chamber where it was connected to three pumps. One pump controlled the pressure at the top of the specimen, one pump controlled the pressure at the bottom of the specimen, and one pump controlled the isostatic confining pressure around the specimen. Deionized water was used as the confining fluid, and an idealized seawater solution was used as the permeant. The confining chamber was filled, and constant pressures were applied to the top and bottom of the specimen 
$(276 \mathrm{kPa})$ and to the confining fluid $(310 \mathrm{kPa})$ to maintain a constant isostatic effective stress $(34 \mathrm{kPa})$ while maintaining $100 \%$ water saturation on the specimen. After a minimum of $8 \mathrm{~h}$ for the saturation phase, each specimen was isostatically consolidated to an isostatic effective stress of $276 \mathrm{kPa}$ by increasing the pressure of the confining fluid and maintaining constant pressure in the sample (i.e., top and bottom pumps). This consolidation phase was applied to close any microcracks in the sample that may have been created by the coring or recovery processes, such that during the permeation phase, we observed the in situ permeability. As our isostatic effective stress is lower than hydrostatic effective stresses, some microcracks may not have closed during consolidation. After stabilization at an isostatic effective stress, flow-through permeability tests were conducted by fixing the pressure gradient across the specimen while maintaining the isostatic effective stress at the center of the specimen. The inlet and outlet fluid volumes were monitored during the experiment, and all experiments were run until steadystate was achieved (inflow and outflow volumes were equal while the sample length and pressure difference remained constant). From the steady-state flow rate, known sample dimensions, and fixed pressure difference across the specimen, the permeability of any specimen was calculated by rearranging Darcy's law:

$$
k=-Q \mu / A \times \Delta l / \Delta P,
$$

where

$$
\begin{aligned}
& Q=\text { steady-state flow rate } \\
& \mu=\text { fluid viscosity, } \\
& A=\text { area of the specimen, } \\
& \Delta l=\text { length of the specimen, and } \\
& \Delta P=\text { fixed pressure difference across the specimen. }
\end{aligned}
$$

Fluid viscosity $(\mu)$ was adjusted for temperature, which was measured continuously during the experiments. Viscosity values did not statistically diverge from a value of $0.001 \mathrm{~Pa} \cdot \mathrm{s}$ (see PERM in "Supplementary material"), which reflects standard laboratory conditions. Sample length was also recorded during the experiments. Sample area was assumed to be constant from the start of the experiment, and was determined from the average of five measurements of sample diameter.

Each calculated permeability is presented at the specimen porosity and depth (Table T3). Specimen porosity after the flow-through experiment was determined in our laboratory from mass and density measurements following the approach presented by
Blum (1997). All mass and density calculations assume standard seawater density $\left(1024 \mathrm{~kg} / \mathrm{m}^{3}\right)$ because samples were saturated with an idealized seawater solution. Interpreted laboratory porosity is similar to the porosity of nearby samples analyzed during Expedition 322 (Fig. F2). Specifically, the laboratory-determined mass and density porosity values are in the range of the shipboard-determined mass and density porosity. It is important to note, however, that the shipboard mass and density porosity data have a significant amount of scatter that has been interpreted as a result of significant coring disturbance (see the "Site C0011" and "Site C0012" chapters [Expedition 322 Scientists, 2010a, 2010b]). Based on the similarity of shipboard and laboratory porosity data, we infer that the laboratory samples also suffer from moderate to significant sample disturbance. This sample disturbance yields a mass and density-based porosity that is likely a high-end estimate of the in situ porosity. Bulk smectite content of samples ranged from 33 to $55 \mathrm{wt} \%$ for samples from Site C0011 and from 31 to $55 \mathrm{wt} \%$ for samples from Site C0012 (Underwood and Guo, 2013). No porosity correction was made for smectite content, so laboratory-based porosity will overestimate true sample porosity (Gamage et al., 2011). Therefore, all references to in situ porosity reflect a high-end value for the in situ porosity.

\section{Experimental results}

All permeability experimental results are summarized in Tables T2 and T3 and presented in Figures F3 and F4 (see PERM in "Supplementary material" for all data files). Nomenclature is provided in Table T4.

CRS consolidation and flow-through permeability experiments allow us to define the range of permeability of sediments at Sites C0011 and C0012 with respect to depth and porosity. We separate discussions based on type of experiment (CRS or flow-through), lithologic unit, and depth trends. To define the depth trends, we assume a log-linear relationship between vertical permeability and depth:

$$
\log \left(k_{\mathrm{v}}\right)=B z+C,
$$

where

$$
\begin{aligned}
& k_{\mathrm{v}}=\text { vertical permeability }\left(\mathrm{m}^{2}\right), \\
& B=\text { permeability model constant } \\
& C=\text { permeability model constant, and } \\
& Z=\text { depth (mbsf) }
\end{aligned}
$$

$B$ and $C$ are determined by a best-fit model to the permeability-depth data. 


\section{CRS consolidation results}

CRS consolidation experiments provide estimates of permeability at Site C0012 from 115.44 to 255.31 mbsf. Based on our CRS experiments, estimates of in situ $k_{\mathrm{v}}$ at Site C0012 range from $1.12 \times 10^{-17}$ to $2.54 \times$ $10^{-18} \mathrm{~m}^{2}$ (Table T2; Figs. F3, F4). CRS-based estimates of in situ $k_{\mathrm{h}}$ at Site C0012 range from $1.66 \times 10^{-17}$ to $6.55 \times 10^{-18} \mathrm{~m}^{2}$. All calculated horizontal permeabilities were higher than vertical permeabilities at equivalent depths, giving permeability ratios $\left(k_{\mathrm{v}} / k_{\mathrm{h}}\right)$ of 0.38-0.99 (Table T2). These permeability estimates document a general decrease with increasing depth (Fig. F3), and a best-fit of the data to Equation 4 yields $B=-0.0046$ and $C=-16.4$, with an excellent goodness of fit $\left(R^{2}=0.99\right)$. Permeability also shows a general decrease with decreasing porosity (Fig. F4).

\section{Flow-through permeability experiments}

Flow-through permeability experiments were used to estimate permeability at Site C0012 from 273.51 to 473.11 mbsf and at Site C0011 from 366.76 to 687.15 mbsf.

At Site C0012, in situ $k_{\mathrm{v}}$ estimates range from $6.09 \times$ $10^{-19}$ to $2.86 \times 10^{-19} \mathrm{~m}^{2}$ (Table T3; Figs. F3, F4). The one in situ $k_{\mathrm{h}}$ estimate at Site C0012 from flowthrough tests was $6.54 \times 10^{-19}$ (Table T2; Figs. F3, F4). The calculated horizontal permeability was higher than vertical permeability at an equivalent depth, giving a permeability ratio $\left(k_{\mathrm{v}} / k_{\mathrm{h}}\right)$ of 0.58 (Table T3). These permeability estimates document a general decrease with increasing depth (Fig. F3), and a best-fit model of the data to Equation 4 yields $B=-0.0011$ and $C=-18.0$; however, the goodness of the fit is low $\left(R^{2}=0.46\right)$. Permeability also shows a general decrease with decreasing porosity (Fig. F4). It should be noted that there is a step-decrease in permeability at Site C0012 moving from 255.23 to $273.51 \mathrm{mbsf}$ (Fig. F3). This decrease corresponds to a change from CRS to flow-through experiments, which was influenced by the stiffness of the samples during trimming; however, there is not a significant change in porosity over this interval (Fig. F4). Therefore, this change in permeability warrants further investigation, as it could be a material property or an experimental artifact.

At Site C0011, in situ $k_{\mathrm{v}}$ estimates range from $7.03 \times$ $10^{-17}$ to $1.38 \times 10^{-18} \mathrm{~m}^{2}$ (Table T3; Figs. F3, F4). One data point (Test PERM072; Table T3) appears to be anomalously high $\left(k_{\mathrm{v}}=7.03 \times 10^{-17} \mathrm{~m}^{2}\right)$ and may be the result of significant sample disturbance (specimen showed cracks after experiment), so we neglect it in depth and porosity trend discussions. Permeability estimates document a general decrease with in- creasing depth (Fig. F3). A best-fit model of the data to Equation 4 yields $B=-0.0010$ and $C=-17.2$; however, the goodness of the fit is low $\left(R^{2}=0.31\right)$. Permeability also shows a general decrease with decreasing porosity (Fig. F4).

Using flow-through data at Sites C0011 and C0012, we compare permeability at equivalent depths and in the same lithologic units. At equivalent depths (below $350 \mathrm{mbsf}$ ), vertical permeability determined by flow-through experiments at Site C0011 is greater than vertical permeability determined by flowthrough experiments at Site C0012 (Fig. F3). In lithologic Units III and IV, flow-through-estimated permeability at Site C0011 is greater than at Site C0012 (Fig. F3; Table T3).

These experimental results provide laboratory-based permeabilities for the interpreted in situ porosity. Ideally laboratory-based studies can provide the in situ porosity and permeability; however, for Sites C0011 and C0012, these data should be considered high-end estimates of in situ porosity and permeability because of significant sample disturbance. Sample disturbance is interpreted from three primary approaches:

1. The laboratory-estimated porosities at in situ conditions are similar to those determined by shipboard analyses (Fig. F2), and the shipboard measurements were interpreted as influenced by sample disturbance imparted by the drilling and coring processes.

2. Sample trimming for these experiments was extremely difficult. In many instances we had to make two or three attempts (each on a new specimen) to trim a competent specimen for experiments. Samples often broke during cutting and trimming. Incorrectly trimmed or visibly disturbed specimens were not used in experiments.

3. One specimen (Test PERM072; Table T3) showed cracks at the end of the experiment. As experimental stresses were low, these cracks could have been preexisting and reopened during the experiment.

We cannot accurately characterize the amount of disturbance on any of the specimens, but we emphasize that because of disturbance there are likely flow paths that were not present in situ. Also, as the flowthrough experiments did not achieve in situ effective stress conditions, they may have higher than in situ porosity and permeability. Therefore our estimated permeability is a high-end estimate (upper limit) of the in situ conditions at any depth.

The presence of sample disturbance and its impact on permeability also suggest that all experimental samples should be carefully selected to minimize dis- 
turbance and that drilling data and reports should be used to look for drilling issues that may have been noted during the drilling and coring process. Such integration of drilling and experimental results cannot remove disturbance but can allow choosing samples with minimum disturbance and promote awareness of the potential problems with permeability estimates.

\section{Summary}

We used CRS consolidation experiments and flowthrough permeability experiments to determine permeability of samples from Sites C0011 and C0012. At Site C0012 (115.44-255.31 mbsf), CRS-based estimates of in situ $k_{\mathrm{v}}$ range from $1.12 \times 10^{-17}$ to $2.54 \times$ $10^{-18} \mathrm{~m}^{2}$ and estimates of in situ $k_{\mathrm{h}}$ range from $1.66 \times$ $10^{-17}$ to $6.55 \times 10^{-18} \mathrm{~m}^{2}$. A log-linear best fit to the permeability-depth data document a downhole decrease in permeability, with an excellent goodness of fit $\left(R^{2}=0.99\right)$. From flow-through experiments on samples from Site C0012, in situ $k_{\mathrm{v}}$ estimates range from $6.09 \times 10^{-19}$ to $2.86 \times 10^{-19} \mathrm{~m}^{2}$ and in situ $k_{\mathrm{h}}$ is $6.54 \times 10^{-19}$. A log-linear (permeability-depth) bestfit model does not yield a strong the goodness of fit $\left(R^{2}=0.46\right)$. Permeability at Site C0012 shows a stepdecrease in permeability from 255.23 to 273.51 mbsf, which corresponds to a change from CRS to flow-through experiments and to a change in sample stiffness. At Site C0011, in situ $k_{v}$ estimates from flow-through experiments range from $7.03 \times 10^{-17}$ to $1.38 \times 10^{-18} \mathrm{~m}^{2}$. Neglecting one anomalous data point, permeability estimates document a general decrease with increasing depth; however, the log-linear (permeability-depth) best-fit model has a low goodness of fit $\left(R^{2}=0.31\right)$. Comparison of flowthrough permeability estimates at Sites C0011 and C0012 documents that permeability at equivalent depths below 350 mbsf at Site C0011 is greater than at Site C0012. In lithologic Units III and IV, flowthrough estimated permeability at Site C0011 is greater than at Site C0012. Porosity data determined shipboard and in the laboratory are consistent and are likely influenced by sample disturbance. Trimming intact laboratory samples was difficult because of cracks and other visible coring disturbance. Based on noted and inferred disturbance, all permeability estimates should be viewed with caution as upper limit estimates of in situ permeability.

\section{Acknowledgments}

This work would not have been possible without the efforts and support of the participants and technical staff of Expedition 322. This research used samples and data provided by the Integrated Ocean Drilling Program (IODP).

\section{References}

ASTM International, 2004. Standard test methods for measurement of hydraulic conductivity of saturated porous materials using a flexible wall permeameter (Standard D5084-03). In Annual Book of ASTM Standards (Vol. 04.08): Soil and Rock (I): West Conshohocken, PA (Am. Soc. Testing and Mater.). http://www.astm.org/DATABASE.CART/HISTORICAL/D5084-03.htm

ASTM International, 2006. Standard test method for onedimensional consolidation properties of saturated cohesive soils using controlled-strain loading (Standard D4186-06). In Annual Book of ASTM Standards (Vol. 04.08): Soil and Rock (I): West Conshohocken, PA (Am. Soc. Testing Mater.) http://www.astm.org/DATABASE.CART/HISTORICAL/D4186-06.htm

Becker, D.E., Crooks, J.H.A., Been, K., and Jeffries, M.G., 1987. Work as a criterion for determining in situ and yield stresses in clays. Can. Geotech. J., 24(4):549-564. doi:10.1139/t87-070

Blum, P., 1997. Physical properties handbook: a guide to the shipboard measurement of physical properties of deep-sea cores. ODP Tech. Note, 26. doi:10.2973/ odp.tn.26.1997

Boutt, D.F., Saffer, D., Doan, M.-L., Lin, W., Ito, T., Kano, Y., Flemings, P., McNeill, L.C., Byrne, T., Hayman, N.W., and Moe, K.T., 2012. Scale dependence of in-situ permeability measurements in the Nankai accretionary prism: the role of fractures. Geophys. Res. Lett., 39(7):L07302. doi:10.1029/2012GL051216

Dugan, B., and Daigle, H., 2011. Data report: permeability, compressibility, stress state, and grain size of shallow sediments from Sites C0004, C0006, C0007, and C0008 of the Nankai accretionary complex. In Kinoshita, M., Tobin, H., Ashi, J., Kimura, G., Lallemant, S., Screaton, E.J., Curewitz, D., Masago, H., Moe, K.T., and the Expedition 314/315/316 Scientists, Proc. IODP, 314/315/316: Tokyo (Integrated Ocean Drilling Program Management International, Inc.). doi:10.2204/

iodp.proc.314315316.208.2011

Ekinci, M.K., Likos, W.J., Underwood, M.B., and Guo, J., 2011. Data report: permeability of mud(stone) samples from IODP Sites C0006 and C0007, Nankai Trough Seismogenic Zone Experiment. In Kinoshita, M., Tobin, H., Ashi, J., Kimura, G., Lallemant, S., Screaton, E.J., Curewitz, D., Masago, H., Moe, K.T., and the Expedition 314/ 315/316 Scientists, Proc. IODP, 314/315/316: Washington, DC (Integrated Ocean Drilling Program Management International, Inc.). doi:10.2204/ iodp.proc.314315316.214.2011

Expedition 322 Scientists, 2010a. Site C0011. In Saito, S., Underwood, M.B., Kubo, Y., and the Expedition 322 Scientists, Proc. IODP, 322: Tokyo (Integrated Ocean Drilling Program Management International, Inc.). doi:10.2204/iodp.proc.322.103.2010 
Expedition 322 Scientists, 2010b. Site C0012. In Saito, S. Underwood, M.B., Kubo, Y., and the Expedition 322 Scientists, Proc. IODP, 322: Tokyo (Integrated Ocean Drilling Program Management International, Inc.). doi:10.2204/iodp.proc.322.104.2010

Gamage, K., Screaton, E., Bekins, B., and Aiello, I., 2011. Permeability-porosity relationships of subduction zone sediments. Mar. Geol., 279(1-4):19-36. doi:10.1016/ j.margeo.2010.10.010

Guo, J., Likos, W.J., Underwood, M.B., Skarbek, R.M., Adamson, N., and Saffer, D., 2011. Data report: consolidation characteristics of sediments from Sites C0002, C0006, and C0007, IODP Expeditions 315 and 316, NanTroSEIZE Stage 1. In Kinoshita, M., Tobin, H., Ashi, J., Kimura, G., Lallemant, S., Screaton, E.J., Curewitz, D., Masago, H., Moe, K.T., and the Expedition 314/315/316 Scientists, Proc. IODP, 314/315/316: Washington, DC (Integrated Ocean Drilling Program Management International, Inc.). doi:10.2204/ iodp.proc.314315316.213.2011

Guo, J., and Underwood, M.B., 2012. Data report: clay mineral assemblages from the Nankai Trough accretionary prism and the Kumano Basin, IODP Expeditions 315 and 316, NanTroSEIZE Stage 1. In Kinoshita, M., Tobin, H., Ashi, J., Kimura, G., Lallemant, S., Screaton, E.J., Curewitz, D., Masago, H., Moe, K.T., and the Expedition 314/315/316 Scientists, Proc. IODP, 314/315/316: Washington, DC (Integrated Ocean Drilling Program Management International, Inc.). doi:10.2204/ iodp.proc.314315316.202.2012

Heki, K., 2007. Secular, transient, and seasonal crustal movements in Japan from a dense GPS array: implication for plate dynamics in convergent boundaries. In Dixon, T.H., and Moore, J.C. (Eds.), The Seismogenic Zone of Subduction Thrust Faults: New York (Columbia Univ. Press), 512-539.

Hüpers, A., and Kopf, A.J., 2012. Data report: consolidation properties of silty claystones and sandstones sampled seaward of the Nankai Trough subduction zone, IODP Sites C0011 and C0012. In Saito, S., Underwood, M.B., Kubo, Y., and the Expedition 322 Scientists, Proc. IODP, 322: Tokyo (Integrated Ocean Drilling Program Management International, Inc.). doi:10.2204/ iodp.proc.322.203.2012

Ikari, M.J., Saffer, D.M., and Marone, C., 2009. Frictional and hydrologic properties of a major splay fault system, Nankai subduction zone. Geophys. Res. Lett., 36(20):L20313. doi:10.1029/2009GL040009

Kopf, A., Strasser, M., Monsees, N., Underwood, M.B., and Guo, J., 2011. Data report: particle size analysis of sediments recovered during IODP Expeditions 315 and 316, Sites C0001-C0008, Nankai Trough forearc, off Japan. In Kinoshita, M., Tobin, H., Ashi, J., Kimura, G., Lallemant, S., Screaton, E.J., Curewitz, D., Masago, H., Moe, K.T., and the Expedition 314/315/316 Scientists, Proc. IODP, 314/315/316: Washington, DC (Integrated Ocean Drilling Program Management International, Inc.). doi:10.2204/iodp.proc.314315316.207.2011
Neuzil, C.E., 1994. How permeable are clays and shales? Water Resour. Res., 30(2):145-150. doi:10.1029/ 93WR02930

Reuschle, T., 2011. Data report: permeability measurements under confining pressure, Expeditions 315 and 316, Nankai Trough. In Kinoshita, M., Tobin, H., Ashi, J., Kimura, G., Lallemant, S., Screaton, E.J., Curewitz, D., Masago, H., Moe, K.T., and the Expedition 314/315/316 Scientists, Proc. IODP, 314/315/316: Washington, DC (Integrated Ocean Drilling Program Management International, Inc.). doi:10.2204/ iodp.proc.314315316.205.2011

Rowe, K., Screaton, E., Guo, J., and Underwood, M.B., 2011. Data report: permeabilities of sediments from the Kumano Basin transect off Kii Peninsula, Japan. In Kinoshita, M., Tobin, H., Ashi, J., Kimura, G., Lallemant, S., Screaton, E.J., Curewitz, D., Masago, H., Moe, K.T., and the Expedition 314/315/316 Scientists, Proc. IODP, 314/315/316: Washington, DC (Integrated Ocean Drilling Program Management International, Inc.). doi:10.2204/iodp.proc.314315316.211.2011

Rowe, K.T., Screaton, E.J., and Ge, S., 2012. Coupled fluid flow and deformation modeling of the frontal thrust region of the Kumano Basin transect, Japan: implications for fluid pressures and décollement downstepping. Geochem., Geophys., Geosyst., 13:Q0AD23. doi:10.1029/2011GC003861

Saffer, D., Guo, J., Underwood, M.B., Likos, W., Skarbek, R.M., Song, I., and Gildow, M., 2011. Data report: consolidation, permeability, and fabric of sediments from the Nankai continental slope, IODP Sites C0001, C0008, and C0004. In Kinoshita, M., Tobin, H., Ashi, J., Kimura, G., Lallemant, S., Screaton, E.J., Curewitz, D., Masago, H., Moe, K.T., and the Expedition 314/315/316 Scientists, Proc. IODP, 314/315/316: Washington, DC (Integrated Ocean Drilling Program Management International, Inc.). doi:10.2204/ iodp.proc.314315316.218.2011

Schneider, J., Flemings, P.B., Day-Stirrat, R.J., and Germaine, J.T., 2011. Insights into pore-scale controls on mudstone permeability through resedimentation experiments. Geology, 39(11):1011-1014. doi:10.1130/ G32475.1

Seno, T., Stein, S., and Gripp, A.E., 1993. A model for the motion of the Philippine Sea plate consistent with NUVEL-1 and geological data. J. Geophys. Res.: Solid Earth, 98(B10):17941-17948. doi:10.1029/93JB00782

Tobin, H.J., and Kinoshita, M., 2006. NanTroSEIZE: the IODP Nankai Trough Seismogenic Zone Experiment. Sci. Drill., 2:23-27. doi:10.2204/iodp.sd.2.06.2006

Underwood, M.B., and Guo, J., 2013. Data report: clay mineral assemblages in the Shikoku Basin, NanTroSEIZE subduction inputs, IODP Sites C0011 and C0012. In Saito, S., Underwood, M.B., Kubo, Y., and the Expedition 322 Scientists, Proc. IODP, 322: Tokyo (Integrated Ocean Drilling Program Management International, Inc.). doi:10.2204/iodp.proc.322.202.2013

Underwood, M.B., Saito, S., Kubo, Y., and the Expedition 322 Scientists, 2010. Expedition 322 summary. In Saito, 
S., Underwood, M.B., Kubo, Y., and the Expedition 322 Scientists, Proc. IODP, 322: Tokyo (Integrated Ocean Drilling Program Management International, Inc.). doi:10.2204/iodp.proc.322.101.2010

Yue, L., Likos, W.J., Guo, J., and Underwood, M.B., 2012. Data report: permeability of mud(stone) samples from Site C0001, IODP Expedition 315, Nankai Trough: NanTroSEIZE Stage 1. In Kinoshita, M., Tobin, H., Ashi, J., Kimura, G., Lallemant, S., Screaton, E.J., Curewitz, D., Masago, H., Moe, K.T., and the Expedition 314/315/316
Scientists, Proc. IODP, 314/315/316: Washington, DC (Integrated Ocean Drilling Program Management International, Inc.). doi:10.2204/

iodp.proc.314315316.204.2012

Initial receipt: 2 September 2012

Acceptance: 17 July 2013

Publication: 24 October 2013

MS 322-208 
Figure F1. Location map for Expedition 322 Sites C0011 (red) and C0012 (white). Orange = NanTroSEIZE Stage 1 drill sites, white barbed line $=$ position of deformation front of accretionary prism, yellow arrows $=$ estimated far-field vectors between the Philippine Sea plate and Japan (Seno et al. 1993; Heki, 2007).

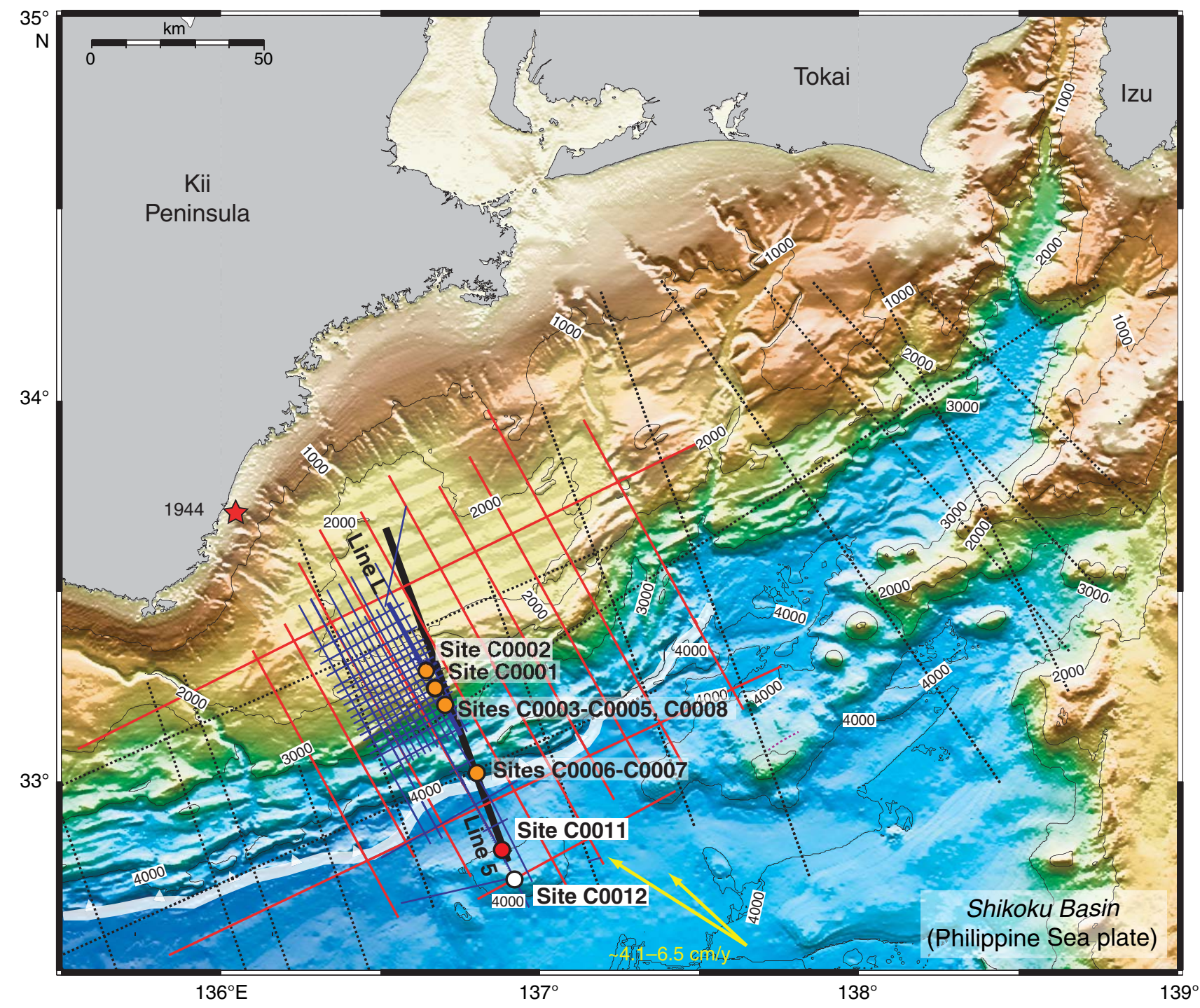


Figure F2. Comparison of moisture and density porosity determined shipboard (black dots) and on laboratory samples used in permeability experiments for Sites C0011 and C0012. Solid red circles = vertically oriented flow-through permeability specimens, open cyan circles $=$ horizontally oriented flow-through permeability specimens, solid red squares = vertically oriented CRS specimens, open cyan squares = horizontally oriented CRS specimens. Shipboard data are from the "Site C0011" and "Site C0012" chapters (Expedition 322 Scientists, 2010a, 2010b).
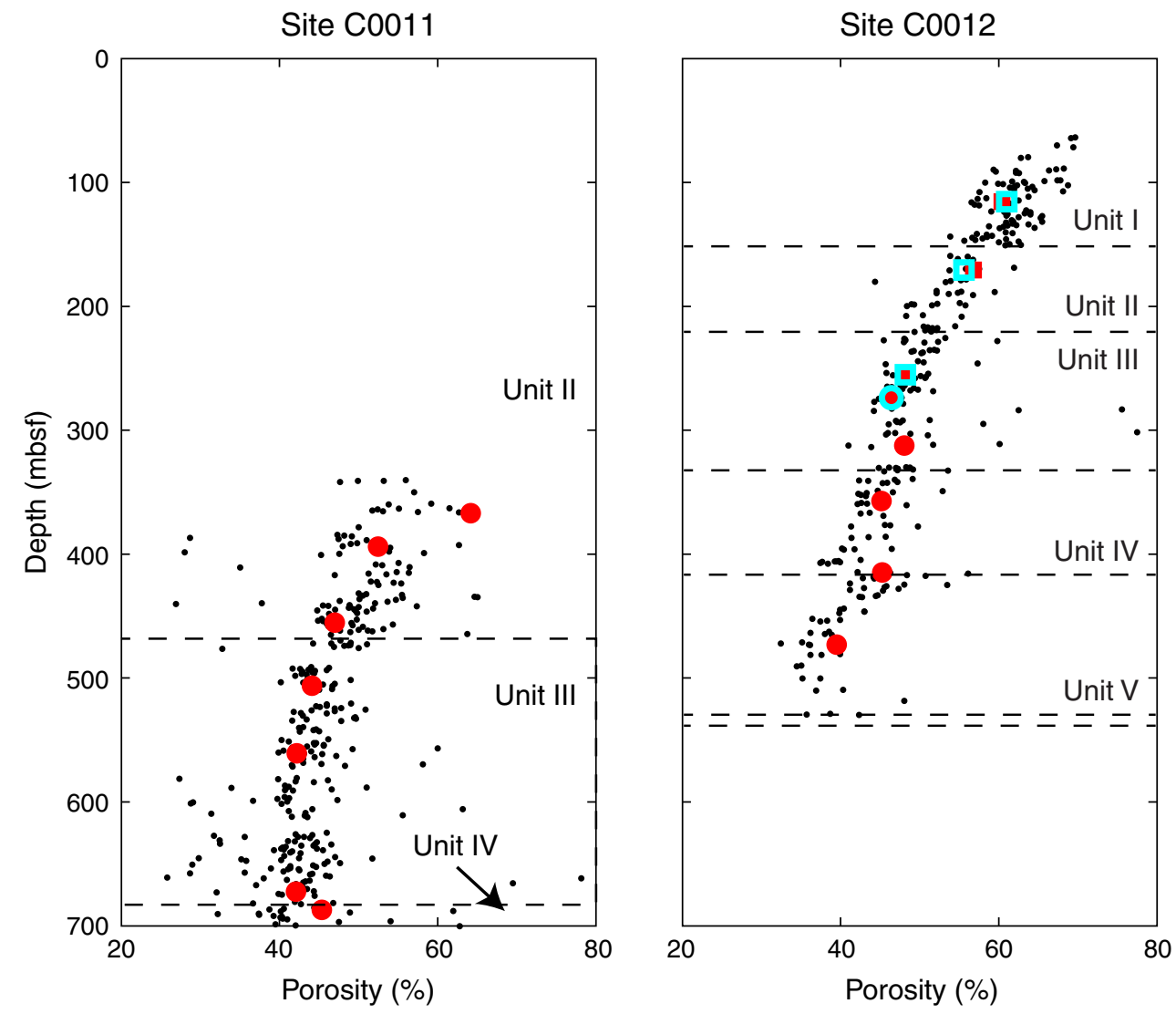
Figure F3. Permeability data for Sites C0011 and C0012 plotted with respect to depth. Permeability is plotted on a log scale. Solid red circles = vertically oriented flow-through permeability specimens, open cyan circles = horizontally oriented flow-through permeability specimens, solid red squares = vertically oriented CRS specimens, open cyan squares $=$ horizontally oriented CRS specimens.
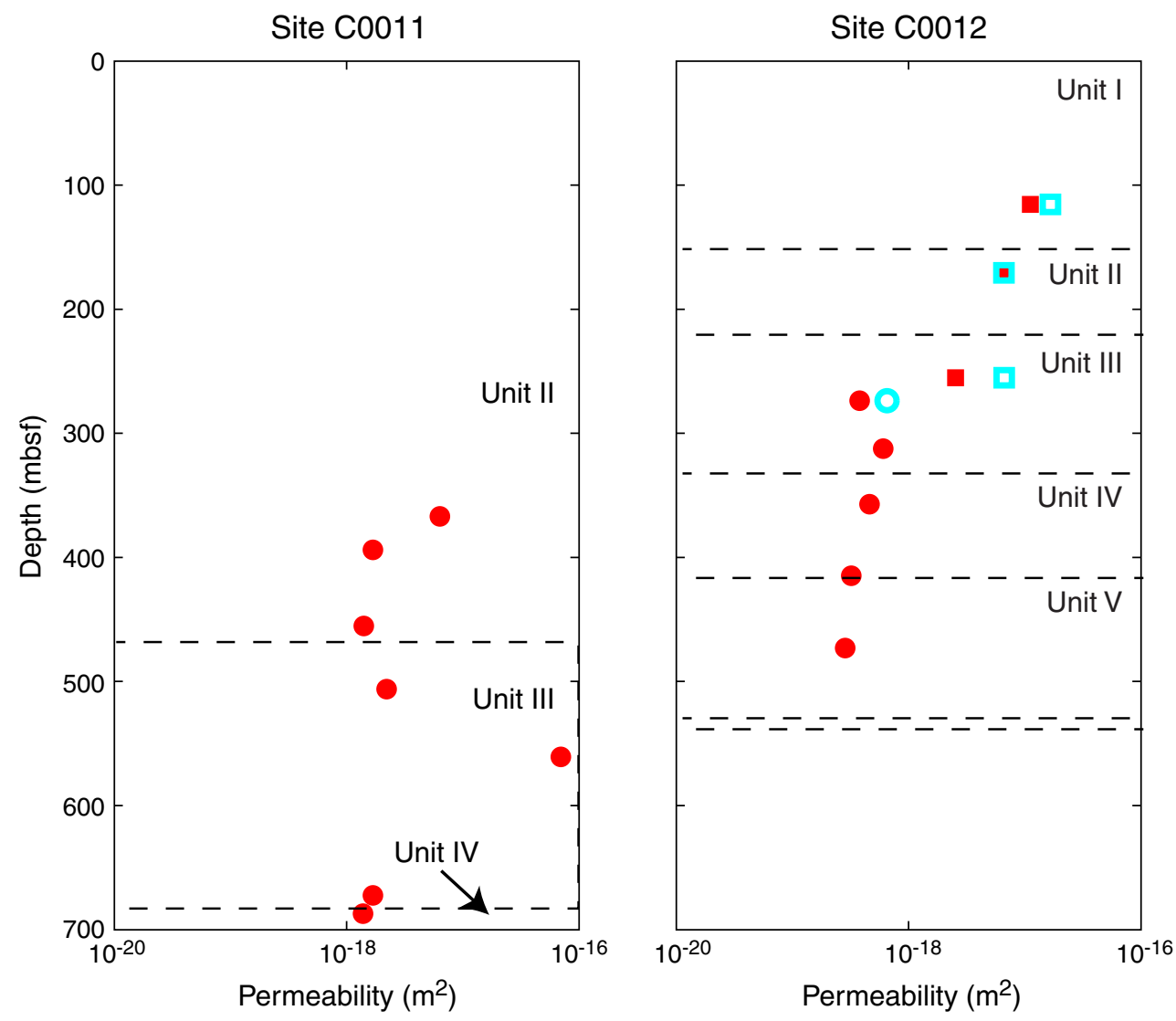
Figure F4. Permeability data for Sites C0011 and C0012 plotted with respect to porosity. Permeability is plotted on a log scale. Solid red circles = vertically oriented flow-through permeability specimens, open cyan circles = horizontally oriented flow-through permeability specimens, solid red squares = vertically oriented CRS specimens, open cyan squares $=$ horizontally oriented CRS specimens.

Site C0011

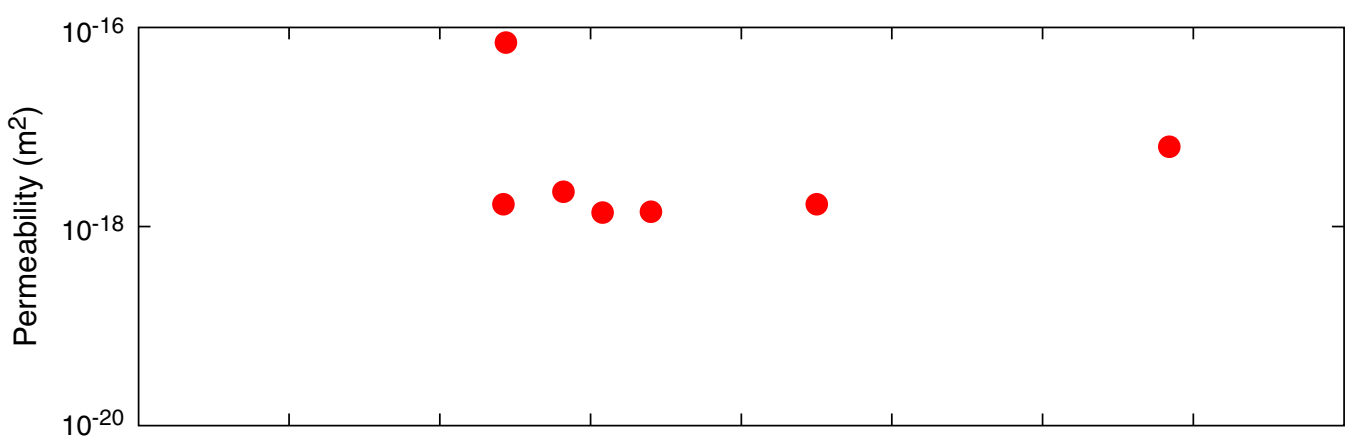

Site $\mathrm{C} 0012$

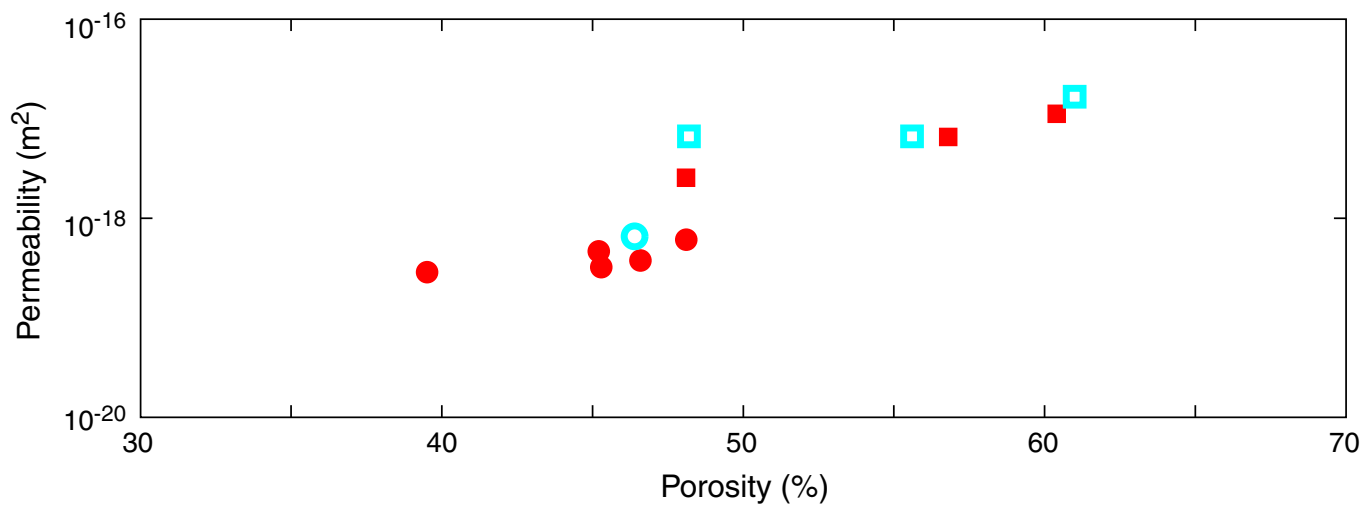


Table T1. Summary of core specimens used for permeability assessment, Sites C0011 and C0012.

\begin{tabular}{|c|c|c|c|c|c|}
\hline Core, section & $\begin{array}{l}\text { Depth } \\
\text { (mbsf) }\end{array}$ & $\begin{array}{c}\text { Test } \\
\text { number }\end{array}$ & $\begin{array}{l}\text { Specimen } \\
\text { orientation }\end{array}$ & Experiment type & $\begin{array}{c}\text { Lithologic } \\
\text { unit }\end{array}$ \\
\hline \multicolumn{6}{|l|}{ 322-C0011B- } \\
\hline $4 \mathrm{R}-2$ & 366.76 & PERM068 & Vertical & Flow-through permeability & II \\
\hline 7R-1 & 394.00 & PERM069 & Vertical & Flow-through permeability & II \\
\hline $13 R-5$ & 455.25 & PERM070 & Vertical & Flow-through permeability & II \\
\hline $21 R-5$ & 506.28 & PERM071 & Vertical & Flow-through permeability & III \\
\hline $27 R-3$ & 560.86 & PERM072 & Vertical & Flow-through permeability & III \\
\hline $40 \mathrm{R}-1$ & 672.20 & PERM074 & Vertical & Flow-through permeability & III \\
\hline $43 R-4$ & 687.15 & PERM075B & Vertical & Flow-through permeability & IV \\
\hline \multicolumn{6}{|l|}{ 322-C0012A- } \\
\hline $8 \mathrm{R}-3$ & 115.44 & CRS073 & Vertical & CRS consolidation & 1 \\
\hline $8 R-3$ & 115.50 & CRS074 & Horizontal & CRS consolidation & 1 \\
\hline $14 \mathrm{R}-3$ & 170.72 & CRS082 & Vertical & CRS consolidation & II \\
\hline $14 \mathrm{R}-3$ & 170.77 & CRS083 & Horizontal & CRS consolidation & II \\
\hline $23 R-2$ & 255.23 & CRS085 & Vertical & CRS consolidation & III \\
\hline $23 R-2$ & 255.31 & CRS086 & Horizontal & CRS consolidation & III \\
\hline $25 \mathrm{R}-1$ & 273.51 & PERM058 & Vertical & Flow-through permeability & III \\
\hline $25 \mathrm{R}-1$ & 273.60 & PERM059 & Horizontal & Flow-through permeability & III \\
\hline $29 \mathrm{R}-2$ & 312.41 & PERM060 & Vertical & Flow-through permeability & III \\
\hline $34 \mathrm{R}-1$ & 357.08 & PERM063 & Vertical & Flow-through permeability & IV \\
\hline $40 \mathrm{R}-1$ & 414.60 & PERM064 & Vertical & Flow-through permeability & IV \\
\hline $46 \mathrm{R}-3$ & 473.11 & PERM065 & Vertical & Flow-through permeability & $\mathrm{V}$ \\
\hline
\end{tabular}

CRS $=$ constant rate of strain.

Table T2. Summary of permeability results from constant rate of strain consolidation experiments, Site C0012.

\begin{tabular}{|c|c|c|c|c|c|c|c|c|c|}
\hline Core, section & $\begin{array}{l}\text { Depth } \\
\text { (mbsf) }\end{array}$ & $\begin{array}{c}\text { Test } \\
\text { number }\end{array}$ & $\begin{array}{l}\text { Specimen } \\
\text { orientation }\end{array}$ & $\begin{array}{l}\text { Porosity } \\
\text { (\%) }\end{array}$ & $k\left(\mathrm{~m}^{2}\right)$ & $k_{\mathrm{v}} / k_{\mathrm{h}}$ & $\begin{array}{l}\sigma_{\mathrm{vh}}^{\prime} \\
(\mathrm{kPa})\end{array}$ & $\begin{array}{l}\sigma_{\mathrm{v}^{\prime} \max } \\
(\mathrm{kPa})\end{array}$ & $\begin{array}{c}\text { Lithologic } \\
\text { unit }\end{array}$ \\
\hline \multicolumn{10}{|l|}{ 322-C0012A- } \\
\hline $8 R-3$ & 115.44 & CRS073 & Vertical & 60.4 & $1.12 \mathrm{E}-17$ & 0.67 & 570 & 2765 & 1 \\
\hline $8 \mathrm{R}-3$ & 115.50 & CRS074 & Horizontal & 61.0 & $1.66 \mathrm{E}-17$ & & 570 & 2543 & 1 \\
\hline $14 R-3$ & 170.72 & CRS082 & Vertical & 56.8 & $6.55 \mathrm{E}-18$ & 0.99 & 868 & 4116 & II \\
\hline 14R-3 & 170.77 & CRS083 & Horizontal & 55.6 & $6.63 \mathrm{E}-18$ & & 868 & 4014 & II \\
\hline $23 R-2$ & 255.23 & CRS085 & Vertical & 48.1 & $2.54 \mathrm{E}-18$ & 0.38 & 1323 & 4123 & III \\
\hline $23 R-2$ & 255.31 & CRS086 & Horizontal & 48.2 & $6.65 \mathrm{E}-18$ & & 1323 & 4119 & III \\
\hline
\end{tabular}

$\sigma_{\mathrm{vh}}{ }^{\prime}=$ effective vertical stress assuming hydrostatic condition, $\sigma_{\mathrm{v}}{ }^{\prime} \max =$ maximum consolidation stress. 
Table T3. Summary of permeability results from flow-through permeability experiments, Sites C0011 and C0012.

\begin{tabular}{|c|c|c|c|c|c|c|c|c|}
\hline Core, section & $\begin{array}{l}\text { Depth } \\
\text { (mbsf) }\end{array}$ & $\begin{array}{c}\text { Test } \\
\text { number }\end{array}$ & $\begin{array}{l}\text { Specimen } \\
\text { orientation }\end{array}$ & $\begin{array}{l}\text { Porosity } \\
\text { (\%) }\end{array}$ & $k\left(\mathrm{~m}^{2}\right)$ & $k_{\mathrm{v}} / k_{\mathrm{h}}$ & $\begin{array}{c}\sigma_{\mathrm{vh}}{ }^{\prime} \\
(\mathrm{kPa})\end{array}$ & $\begin{array}{c}\text { Lithologic } \\
\text { unit }\end{array}$ \\
\hline \multicolumn{9}{|l|}{ 322-C0011B- } \\
\hline $4 \mathrm{R}-2$ & 366.76 & PERM068 & Vertical & 64.2 & $6.32 \mathrm{E}-18$ & & 6353 & II \\
\hline 7R-1 & 394.00 & PERM069 & Vertical & 52.5 & $1.68 \mathrm{E}-18$ & & 6818 & II \\
\hline $13 R-5$ & 455.25 & PERM070 & Vertical & 47.0 & $1.41 \mathrm{E}-18$ & & 7864 & II \\
\hline $21 \mathrm{R}-5$ & 506.28 & PERM071 & Vertical & 44.1 & $2.22 \mathrm{E}-18$ & & 8735 & III \\
\hline $27 \mathrm{R}-3$ & 560.86 & PERM072 & Vertical & 42.2 & $7.03 \mathrm{E}-17$ & & 9668 & III \\
\hline 40R-1 & 672.20 & PERM074 & Vertical & 42.1 & $1.68 \mathrm{E}-18$ & & 11570 & III \\
\hline $43 R-4$ & 687.15 & PERM075B & Vertical & 45.4 & $1.38 \mathrm{E}-18$ & & 11825 & IV \\
\hline \multicolumn{9}{|l|}{ 322-C0012A- } \\
\hline $25 \mathrm{R}-1$ & 273.51 & PERM058 & Vertical & 46.6 & 3.77E-19 & 0.58 & 1421 & III \\
\hline $25 \mathrm{R}-1$ & 273.60 & PERM059 & Horizontal & 46.4 & $6.54 \mathrm{E}-19$ & & 1422 & III \\
\hline $29 \mathrm{R}-2$ & 312.41 & PERM060 & Vertical & 48.1 & $6.09 \mathrm{E}-19$ & & 1631 & III \\
\hline $34 \mathrm{R}-1$ & 357.08 & PERM063 & Vertical & 45.2 & $4.64 \mathrm{E}-19$ & & 1871 & IV \\
\hline 40R-1 & 414.60 & PERM064 & Vertical & 45.3 & $3.20 \mathrm{E}-19$ & & 2181 & IV \\
\hline $46 \mathrm{R}-3$ & 473.11 & PERM065 & Vertical & 39.5 & 2.86E-19 & & 2496 & V \\
\hline
\end{tabular}

$\sigma_{\mathrm{vh}}{ }^{\prime}=$ effective vertical stress assuming hydrostatic conditions.

Table T4. Nomenclature, Expedition 322.

\begin{tabular}{lllc}
\hline Variable & \multicolumn{1}{c}{ Definition } & Dimension & Unit \\
\hline$A$ & Specimen cross-sectional area & $\mathrm{L}^{2}$ & $\mathrm{~m}^{2}$ \\
$B$ & Permeability model constant & - & - \\
$\mathrm{C}$ & Permeability model constant & - & - \\
$\mathrm{g}$ & Acceleration due to gravity & $\mathrm{L} / \mathrm{T}^{2}$ & $\mathrm{~m} / \mathrm{s}^{2}$ \\
$H$ & Instantaneous specimen height & $\mathrm{L}$ & $\mathrm{m}$ \\
$H_{\mathrm{o}}$ & Initial specimen height & $\mathrm{L}$ & $\mathrm{m}$ \\
$K$ & Hydraulic conductivity & $\mathrm{L} / \mathrm{T}$ & $\mathrm{m} / \mathrm{s}$ \\
$k$ & Permeability & $\mathrm{L}^{2}$ & $\mathrm{~m}^{2}$ \\
$k_{\mathrm{h}}$ & Horizontal permeability & $\mathrm{L}^{2}$ & $\mathrm{~m}^{2}$ \\
$k_{\mathrm{v}}$ & Vertical permeability & $\mathrm{L}^{2}$ & $\mathrm{~m}$ \\
$P_{\mathrm{p}}$ & Pore pressure & $\mathrm{M} / \mathrm{LT}^{2}$ & $\mathrm{kPa}$ \\
$P_{\mathrm{c}}$ & Cell pressure & $\mathrm{M} / \mathrm{LT}^{2}$ & $\mathrm{kPa}$ \\
$Q$ & Volumetric flow rate & $\mathrm{L}^{3} / \mathrm{T}$ & $\mathrm{m} / \mathrm{s}$ \\
$Z$ & Meters below seafloor & $\mathrm{L}$ & $\mathrm{m}$ \\
$\Delta l$ & Specimen length & $\mathrm{L}$ & $\mathrm{m}$ \\
$\Delta P$ & Pressure difference across specimen & $\mathrm{M} / \mathrm{LT}^{2}$ & $\mathrm{kPa}$ \\
$\dot{\varepsilon}$ & Strain rate & $1 / \mathrm{T}$ & $1 / \mathrm{s}$ \\
$\phi$ & Porosity & $\mathrm{L}^{3} / \mathrm{L}^{3}$ & $\mathrm{~m} / \mathrm{m}^{3}$ \\
$\rho_{\mathrm{b}}$ & Bulk density & $\mathrm{M} / \mathrm{L}^{3}$ & $\mathrm{~kg} / \mathrm{m}^{3}$ \\
$\rho_{\mathrm{w}}$ & Seawater density & $\mathrm{M} / \mathrm{L}^{3}$ & $\mathrm{~kg} / \mathrm{m}^{3}$ \\
$\sigma_{\mathrm{a}}$ & Total axial stress & $\mathrm{M} / \mathrm{LT}^{2}$ & $\mathrm{kPa}$ \\
$\sigma_{\mathrm{vh}} \mathrm{N}^{\prime}$ & Hydrostatic effective vertical stress & $\mathrm{M} / \mathrm{LT}^{2}$ & $\mathrm{kPa}$ \\
$\sigma_{\mathrm{v}}^{\prime}$ max & Maximum consolidation stress & $\mathrm{M} / \mathrm{LT}^{2}$ & $\mathrm{kPa}$ \\
$\Delta u$ & Base excess pressure & $\mathrm{M} / \mathrm{LT}^{2}$ & $\mathrm{kPa}$ \\
$\mu$ & Dynamic viscosity & $\mathrm{M} / \mathrm{LT}$ & $\mathrm{Pa} \cdot \mathrm{s}$ \\
\hline
\end{tabular}

$-=$ not applicable. 